\title{
Myeloprotective and hematoprotective role of kefir on cyclophosphamide toxicity in rats
}

\author{
Kefirin Sıçanlarda Oluşturulmuş Siklofosfamid Toksisitesi Üzerine Myeloprotektif Ve Hematoprotektif \\ Etkileri
}

\author{
Gülay Gözüoğlu ${ }^{1}$, Songül Çetik Yıldız ${ }^{1}$
}

\begin{abstract}
Aim: Kefir is a probiotic and prebiotic beverage produced from milk and kefir grains containing a mixture of bacteria and yeast. Drugs like cyclophosphamide (CPx) that are used for cancer chemotherapy are generally limited due to numerous unwanted side-effects such as multiple organ toxicity. For this purpose, the cellprotective effects of kefir, a natural probiotic known for its antitumor and antioxidant properties, on $\mathrm{CPx}$ induced hemotoxicity and myelotoxicity were investigated in this study.

Methods: Group 1 (control, $0.5 \mathrm{ml} \mathrm{SF}$ ). Group 2 were administered a single dose of 150mg/kg CPx. Group 3 and 5 were given 5 and $10 \mathrm{mg} / \mathrm{kg}$ kefir. Group 4 and 6 were given 5 and $10 \mathrm{mg} / \mathrm{kg} \mathrm{kefir}+150 \mathrm{mg} / \mathrm{kg} \mathrm{CPx}$. While kefir was administered to the rats by gavage method for 12 days, CPx was administered as single-dose on the 12th day.

Results: The DPPH results showed that kefir possesses high antioxidant activity. It was observed that the leukocytes, thrombocytes, erythrocytes, hemoglobin, hematocrit and bone marrow nucleated cell levels decreased in the group that was administered only $\mathrm{CPx}$, and increased relatively in the groups that were administered $\mathrm{CPx}+\mathrm{kefir}$, drawing close to the control.

Conclusion: The results of the present study showed that kefir had antioxidant and cytoprotective activity, protecting blood and bone marrow cells against $\mathrm{CPx}$-induced damage.
\end{abstract}

Keywords: Kefir, CPx, myelotoxicity, hemotoxicity, rat

\footnotetext{
Öz

Amaç: Kefir, bakteri ve maya karışımı içeren kefir taneleri ile sütten üretilen probiyotik ve prebiyotik bir içecektir. Siklofosfamid (CPx) gibi kanser kemoterapisi için kullanılan ilaçların kullanımı, genellikle, istenmeyen çoklu organ toksisitesi gibi yan etkiler nedeniyle sınırlıdır. Bu amaçla yapılan çalışmamızda antitümör ve antioksidan özellikleri iyi bilinen ve doğal bir probiyotik olan kefirin CPx nedenli hemotoksisite ve myelotoksisite üzerine koruyucu etkileri araştırılmıştır.

Gereç ve Yöntem: Grup 1 (kontrol, 0,5 ml SF), grup 2; tek doz $150 \mathrm{mg} / \mathrm{kg} / \mathrm{b}$.w $/ \mathrm{i} . \mathrm{p}$ CPx, Grup 3; $5 \mathrm{mg} / \mathrm{kg} / \mathrm{b} . \mathrm{w}$ kefir, grup 4; $5 \mathrm{mg} / \mathrm{kg} / \mathrm{b} . \mathrm{w}+150 \mathrm{mg} / \mathrm{kg} / \mathrm{b}$.w/i.p CPx, grup $5 ; 10 \mathrm{mg} / \mathrm{kg} / \mathrm{b}$.w kefir, Grup $6 ; 10 \mathrm{mg} / \mathrm{kg} / \mathrm{b} . \mathrm{w}$ kefir $+150 \mathrm{mg} / \mathrm{kg} /$ b.w/i.p CPx. Kefir, hayvanlara gavaj yöntemiyle 12 gün boyunca verildi. CPx ise 12. gün tek doz olarak verildi. Deney sonunda tüm sıçanlardan kan ve kemikiliği örnekleri anestezi altında alındı.

Bulgular: DPPH sonuçları kefirin yüksek antioksidan aktiviteye sahip olduğunu göstermiştir. Sadece CPx uygulanan grupta lökosit, trombosit, eritrosit, hemoglobin, hematokrit ve kemik iliği çekirdekli hücre düzeylerinin azaldığı, CPx+kefir verilen gruplarda ise göreceli olarak arttığı ve kontrole yaklaştı̆̆ gözlendi.

Sonuç: Sonuçlarımız antitümör, antioksidan ve sitoprotektif özellikleri olan kefirin kan ve kemik iliği hücrelerini CPx hasarına karşı koruduğunu göstermiştir.
}

Anahtar sözcükler: Kefir, Siklofosfamid, Myelotoksisite, Hemotoksisite, ra
1 Mardin Artuklu University, The Institute for Graduate Educational Studies, Department of Biology, Mardin, Turkey.

GG: 0000-0001-9903-9754

SÇY: 0000-0002-7855-5343

Ethics Committee Approval: This study was approved by the Eskisehir Osmangazi University Local Ethics Committee of Animal Experiments (784-145 / 2020).

Etik Kurul Onayı: Bu çalışma Eskisehir Osmangazi Üniversitesi Hayvan Deneyleri Yerel Etik Kurulu'ndan onay alınmıștır (784-145 / 2020).

Conflict of Interest: No conflict of interest was declared by the authors.

Çıkar Çatışması: Yazar çıkar çatışması bildirmemiștir.

Financial Disclosure: This experimental research was financed by Mardin Artuklu University / Coordination Unit of Scientific Research Project (MAÜ.BAP.20.SHMYO.004)

Finansal Destek: $\mathrm{Bu}$ çalışma Mardin Artuklu Üniversitesi Bilimsel Araştırma Projeleri Koordinatörlüğü tarafından desteklenmiştir (MAÜ.BAP.20.SHMYO.004)

This study was presented on 4th the International Health Sciences Conference 2020 (IHSC 2020) held in Dicle University, Diyarbakır, Turkey, 5-6 November 2020. $\mathrm{Bu}$ çalışma 4th the International Health Sciences Conference 2020 (IHSC 2020), Dicle University, Diyarbakır, Turkey, 5-6 November 2020 sunulmuştur.

Geliş Tarihi / Received: 26.03.2021

Kabul Tarihi / Accepted: 26.07.2021

Yayın Tarihi / Published: 02.08.2021

Sorumlu yazar / Corresponding author Songül Çeltik Yıldız

Adres/Address: Department of Biology, The Institute for Graduate Educational Studies, Mardin Artuklu University, 47200, Mardin, Turkey.

e-mail: songulcetik@gmail.com

Tel/Phone: +90-482-2134002 / 7270

Copyright $\odot$ ACEM 


\section{Introduction}

Todays, the demand for probiotic, prebiotic and functional food products in particular has been gradually increasing [1]. Probiotic microorganisms can improve intestinal barrier integrity and immune response while preventing the negative effects of pathogens [2]. Prebiotics, on the other hand, are short-chain carbohydrates that selectively reinforce the activity of certain beneficial bacteria groups that cannot be digested by human digestive enzymes [3]. Kefir contains high amounts of probiotics and prebiotics [4]. Kefir grains contain a rich microbial community consisting of a microflora of yeast and bacteria responsible for the fermentation of kefir $[5,6]$. Lactobacilli constitute $65-80 \%$ of the microbial structure in kefir while streptococci account for $20 \%$ and yeast make up 5\% [7]. As a result of the synthesis of certain vitamins, the development of bioactive substances and the partial fragmentation of lactose and proteins with the effect of the fermentation induced by the microorganisms in its formation, the nutritional value of kefir increases further [8]. Kefir also contains certain fatty acids and essential amino acids that must be obtained through nutrition [9], Vitamins B1, B2, B6 and B12, folic acid, Vitamin K, biotin (vit $\mathrm{H}$ ), macrominerals such as calcium, phosphorus, potassium, magnesium, and microminerals such as zinc, copper, manganese, iron and cobalt $[4,10]$. It has been determined in many studies that kefir consumption had positive and regulatory effects on the immune system [10-12]. A previous experimental study has shown that the microorganisms in kefir could significantly affect the immunoregulatory properties in rats [13]. It has been shown that kefir reduces lipid peroxidation and positively affects the antioxidant parameters in carbon tetrachloride-induced toxicity in rats [14]. Kefir possesses antioxidative, antimicrobial, anticarcinogenic properties and demonstrates anti-apoptotic activity $[10,15,16]$.

Leukopenia, thrombocytopenia and lymphopenia develop due to the immunosuppressive effects of alkylating drugs. Therefore, high doses and/or more frequent use of such drugs prevent stronger therapeutic efficacy [17]. High-dose alkylating agents such as Cyclophosphamide (CPx) are needed to be used in effective doses in order to be efficient [18]. However, the use of high-dose cytotoxic drugs and the prolongation of patients' survival time also increase the side-effects of the drugs [19]. CPx is a cytotoxic drug that can repress both humoral and cellular immunity [20]. CPx, an alkylating chemotherapeutic prodrug, is metabolized by cytochrome P450 liver enzymes, i.e. CYP3A4 and CYP2B6, which show active therapeutic and cytotoxic metabolites and spread from hepatocytes to plasma [21]. CPx spreads to the body and produces two active metabolites: phosphoramide mustard (PAM) and acrolein (ACR). While the immunosuppressive and antineoplastic effects of CPx are related to PAM, ACR is responsible for its unwanted toxicity [22]. ACR produces oxidative stress in hepatocytes and highly-reactive oxygen species [23]. Therefore, it damages the antioxidant defense mechanism of tissue as it causes changes in the structure and functions of enzymes by interacting with proteins [24]. CPx, which has been known to be effective in the treatment of cancer and non-malignant diseases since 1958 and has a wide area of use in many neoplastic diseases as a standalone drug or in combination with other chemotherapeutics, also includes side-effects [25]. The fact that CPx causes multi-organ damage limits the effective high-dose use of the drug [26]. Hematopoietic depression is among the main side-effects of CPX. CPX includes considerable toxic side-effects such as hematoxicity, bone marrow suppression, carcinogenicity and mutagenicity [11]. In CPx chemotherapy, these toxic effects must be eliminated using certain antioxidant agents in order to avoid the toxic side-effects of acrolein [27]. For this purpose, in the present experimental study, the potential antioxidant and cytoprotective effects of kefir on peripheral blood and bone marrow nucleated cells in $\mathrm{CPx}$-induced toxicity in rats were investigated.

\section{Material and methods}

\section{Kefir fermentation}

In the present study, commercially available freezedried kefir grains and 1 liter of cow's milk were used. For the kefir fermentation, the method adopted by Marshall et al., (28) was used. For the fermentation process, three groups of kefir classified as 24, 36 and 48 hours were created at a temperature of $24-26^{\circ} \mathrm{C}$ and preserved for use at $+4^{\circ} \mathrm{C}$. Kefir groups fermented on different days were used due to the formation of different microbial flora around the kefir grains.

\section{Chemical Substances and Injections}

CPx (Sigma-Aldrich) was obtained commercially. 500 $\mathrm{mg}$ of CPx was dissolved in $25 \mathrm{ml}$ of bidistilled water and 150 $\mathrm{mg} / \mathrm{kg}$ of CPx was made ready for injection. The injection was administered intraperitoneally as a single-dose using sterile disposable syringes on the 12th day of the experiment.

Also DPPH solution (in 60 micromolar in methanol) was obtained commercially.

Determination of antioxidant capacity (Scavenging activity on 2,2-diphenyl-1-picrylhydrazyl (DPPH) radical)

The milk (using as control) used for kefir fermentation and waited for 24, 36, 48 hours were weighed as 2 g samples. 20 $\mathrm{ml}$ of methanol $(75 \%)$ was added on it. Stirred with magnetic stirrer in the dark for 4 hours. It was centrifuged (3500 rpm, 30 minutes, room temperature). The supernatant was put into a tube. The final volume was adjusted to $22 \mathrm{ml}$ with $75 \%$ methanol. 100 $\mu l$ extract was put into a tube. $3.9 \mathrm{ml}$ DPPH solution was added on it and the absorbance was read at $517 \mathrm{~nm}$ by leaving it to incubate for 30 minutes. In blind reading (blank), the solvent was used instead of the sample (solvent only). Only DPPH solution + solvent were used for control purposes. The antioxidant activity was given as percentage (\%) DPPH scavenging, calculated as [(control absorbance-extract absorbance)/(control absorbance) $\square$ 100]. The extract concentration providing $50 \%$ inhibition (IC50) was calculated from the graph of scavenging effect percentage against extract concentration.

\section{Experimental Groups}

In the present experimental study; healthy male Wistar albino rats that were approximately 3 months old and weighing $200 \pm 20$ grams were used. Throughout the experiment, the animals were kept in rooms with $12 ; 12$ bright/dark lighting, automatically adjusted to $22 \pm 2 \mathrm{C}^{\circ}$ temperature and $45-50 \%$ humidity. Standard pellet feed and tap water were provided to the rats. The 42 rats used in the present study were divided into 6 groups with 7 in each group. Group 1 used as control. Group 2 were administered a single dose of $150 \mathrm{mg} / \mathrm{kg} / \mathrm{b}$.w. CPx while Group 3 was given $5 \mathrm{mg} / \mathrm{kg} / \mathrm{b}$.w. kefir, Group 4 was given 5 $\mathrm{mg} / \mathrm{kg} / \mathrm{b}$.w. kefir+150 mg/kg/b.w. CPx, Group 5 was given 10 $\mathrm{mg} / \mathrm{kg} / \mathrm{b}$.w. kefir and Group 6 was given $10 \mathrm{mg} / \mathrm{kg} / \mathrm{b}$.w. kefir+150 mg/kg/b.w. CPx (Table 1). Kefir was administered to the groups for 12 days using the gavage method. CPx was administered as single-dose and intraperitoneal (i.p.) at the 12th and final day of the experiment. 
Table 1: Experimental groups, kefir and injection protocol.

\begin{tabular}{llc} 
Groups & Treatment & $\begin{array}{l}\text { The } \\
\text { number } \\
\text { of rats }\end{array}$ \\
\hline Control & $0.5 \mathrm{ml} \mathrm{SF}$ & 7 \\
Cyclophosphamide (CPx) & $150 \mathrm{mg} / \mathrm{kg} / \mathrm{b} . \mathrm{w} \mathrm{CPx}$ & 7 \\
Kefir & 5 and $10 \mathrm{mg} / \mathrm{kg} / \mathrm{b} . \mathrm{w}$ kefir & 7 \\
Kefir $+\mathrm{CPx}$ & 5 and $10 \mathrm{mg} / \mathrm{kg} \mathrm{b.w} \mathrm{kefir}+$ & 7 \\
& $150 \mathrm{mg} / \mathrm{kg} / \mathrm{b} . \mathrm{w} \mathrm{CPx}$ & \\
\hline
\end{tabular}

Peripheral blood and bone marrow nucleated cell

count

Following the conclusion of the experiment, all of the rats were dissected under ketamine/xylazine anesthesia on the 13th day. Approximately $5 \mathrm{ml}$ of blood was taken intracardially into tubes containing $3.8 \%$ sodium citrate $(1: 9$, sodium citrate: blood). The blood taken from the rats in each experimental group was immediately counted in the rat calibration of the Hemavet 850 hematology analyzer. Afterwards, the statistical analyzes of the leukocyte, thrombocyte, erythrocyte, hemoglobin and hematocrit values obtained were performed using the SPSS 22.0 statistical package program. Following this process, a femur of the euthanized animals was exposed by thoroughly scraping off the muscles. The bone marrow was cut at both ends, held with pliers and placed entirely into the tube. To ensure the homogeneous distribution of the cells in the graduated tube containing $5 \mathrm{ml}$ of physiological saline solution and bone marrow, the cellular fluid in the tube was drawn and emptied several times using the same injector. During this process, it was ensured that the fluid did not boil over. The tubes containing bone marrow were centrifuged at $3000 \mathrm{rpm}$ for 5 minutes and the supernatant was drawn using the injector. The mixture was homogenized, and a bone marrow count was performed using the hematology analyzer.

\section{Statistical analysis}

The analysis of the present study was performed in a computer environment using the SPSS 11.0 statistical program. In the analysis, the One-Way ANOVA test was used to determine the importance of intergroup differentiation and the arithmetic mean \pm standard deviation of the measurement data. If significant differentiation was detected in the analysis of variance, paired comparisons were performed using the Post Hoc Tukey test. The significance level was regarded as $\mathrm{p}<0.001$. Differences between the means obtained from DPPH, acidity and $\mathrm{pH}$ analyzes were analyzed by Duncan Multiple Comparison Test $(\mathrm{p}<0.05)$.

\section{Results}

The kefir samples, which were fermented for 24, 36 and 48 hours, were quantitatively tested for free radical scavenging activity using a DPPH. The samples were also tested for the $\mathrm{pH}$ and acidity. Our results showed that kefir that had been stored for 24,36 , and $48 \mathrm{~h}$ had strong antioxidant activity compared to milk. However, there was not found any significant difference between the 24, 36 and $48 \mathrm{~h}$. While the acidity gradually increased on the 24,36 and $48 \mathrm{~h}$ kefir, the $\mathrm{pH}$ gradually decreased (Table 2).

In the present study, the changes in blood and bone marrow nucleated cell levels were analyzed to determine the toxic effect of CPx and the changes that occur based on the antioxidant feature of kefir. In the group that was administered $\mathrm{CPx}$, the bone marrow nucleated cell level demonstrated a statistically significant decrease compared to the control values $(p<0.001)$. In comparison with the group that was administered only CPx, the bone marrow nucleated cell level of Groups 4 and 6, which were administered kefir in combination with $\mathrm{CPx}$, demonstrated a statistically significant increase (particularly Group 6) and this level drew even closer to the control value with the increase in Group $6(\mathrm{p}<0.001)$. In Groups 3 and 5, which were administered 5 and $10 \mathrm{mg} / \mathrm{kg}$ kefir, the bone marrow nucleated cell level was found to be higher than the control value, albeit not statistically significant (Table 3, Figure 1). Compared to the control value, the leukocyte level demonstrated a statistically significant decrease in the group that was administered CPx $(\mathrm{p}<0.001)$. When Group 2, which was administered CPx, was compared to Groups 4 and 6, which were administered $\mathrm{CPx}+\mathrm{kefir}$, a statistically significant increase was observed in the leukocyte level $(\mathrm{p}<0.001)$. In Groups 3 and 5, which were administered 5 and $10 \mathrm{mg} / \mathrm{kg}$ kefir, the leukocyte level was found to be higher than the control value, albeit not statistically significant (Table 3, Figure 2). Regarding the thrombocyte level, there was a statistically significant decrease in the CPx group compared to the control value $(\mathrm{p}<0.001)$. In Groups 4 and 6, which were administered kefir in combination with CPx, this level increased significantly and drew near the control value $(\mathrm{p}<0.001)$. In Groups 3 and 5 , which were administered 5 and $10 \mathrm{mg} / \mathrm{kg}$ kefir, the thrombocyte level was found to be higher than the control value, and this is statistically significant ( $\mathrm{p}<0.001$ ) (Table 3, Figure 3). In the CPx group, the erythrocyte level demonstrated a statistically significant decrease compared to the control value $(\mathrm{p}<0.001)$. In the groups that were administered kefir in combination with $\mathrm{CPx}$, a significant increase was observed in the erythrocyte level (particularly in Group 6) $(\mathrm{p}<0.001)$. In Groups 3 and 5, which were administered 5 and $10 \mathrm{mg} / \mathrm{kg}$ kefir, this value was higher than the control value, and this is statistically significant ( $\mathrm{p}<0.001)$ (Table 3, Figure 4). In Group 2, which was administered CPx, the hemoglobin level demonstrated a significant decrease compared to the control value $(\mathrm{p}<0.001)$. In Groups 4 and 6 , which were administered CPx+kefir, a statistically significant increase was observed in the hemoglobin level and with this increase, the hemoglobin level drew near the control value particularly in Group $6(\mathrm{p}<0.001)$. In Groups 3 and 5, which were administered 5 and $10 \mathrm{mg} / \mathrm{kg}$ kefir, the hemoglobin level was found to be higher than the control value (particularly in Group 5) (Table 3, Figure 5). In Group 2, which was administered only CPx, the hematocrit value demonstrated a significant decrease compared to the control value $(\mathrm{p}<0.001)$. In Groups 4 and 6 , which were administered kefir in combination with $\mathrm{CPx}$, this level increased significantly and drew close to the control value to a large extent $(\mathrm{p}<0.001)$. This value was also high in Groups 3 and 5, which were administered 5 and $10 \mathrm{mg} / \mathrm{kg}$ kefir, albeit not statistically significant (Table 2, Figure 6).

Table 2: Antioxidant (inhibition of DPPH free radical), acidity and $\mathrm{pH}$ of 24, 36, 48 hours kefir groups and milk (used as control) stored at $4^{\circ} \mathrm{C}$.

\begin{tabular}{llcc}
\hline Samples & $\begin{array}{l}\text { Antioxidant } \\
\text { (\%Inhibition of } \\
\text { DPPH free radical) }\end{array}$ & Acidity (\%) & $\mathrm{pH}$ \\
\hline Milk & ${ }^{*} 15.93 \pm 0.9^{\mathrm{a}^{* *}}$ & $0.09 \pm 0.003^{\mathrm{a}}$ & $6.91 \pm 0.01^{\mathrm{a}}$ \\
Kefir $-24 \mathrm{~h}$ & $30.01 \pm 0.06^{\mathrm{b}}$ & $0.36 \pm 0.005^{\mathrm{b}}$ & $5.81 \pm 0.02^{\mathrm{b}}$ \\
Kefir $-36 \mathrm{~h}$ & $30.18 \pm 0.10^{\mathrm{b}}$ & $0.930 \pm 0.009^{\mathrm{c}}$ & $4.34 \pm 0.01^{\mathrm{c}}$ \\
Kefir $-48 \mathrm{~h}$ & $30.29 \pm 0.05^{\mathrm{b}}$ & $1.340 \pm 0.009^{\mathrm{d}}$ & $4.28 \pm 0.0^{\mathrm{d}}$ \\
\hline
\end{tabular}


Table 3. The impact of 5 and $10 \mathrm{mg} / \mathrm{kg}$ kefir on bone marrow nucleated cell, erythrocyte, leukocyte, thrombocyte, hemoglobin and hematocrit count against $150 \mathrm{mg} / \mathrm{kg} \mathrm{CPx}$ toxicity.

\begin{tabular}{|c|c|c|c|c|c|c|}
\hline Groups & $\begin{array}{l}\text { Bone marrow } \\
\text { nucleated cells } \\
\left(\times 10^{3} / \mathrm{ml}\right)\end{array}$ & $\begin{array}{l}\text { Leucocytes } \\
\left(\times 10^{3} / \mathrm{ml}\right)\end{array}$ & $\begin{array}{l}\text { Thrombocytes } \\
\left(\times 10^{3} / \mathrm{ml}\right)\end{array}$ & $\begin{array}{c}\text { Erythrocytes } \\
\left(\times 10^{3} / \mathrm{ml}\right)\end{array}$ & Hemoglobin & Hematocrit \\
\hline 1- Control & $3536.00 \pm 61.11^{\mathrm{a}}$ & $825.67 \pm 40.41^{\mathrm{a}^{*}}$ & $725.50 \pm 36.64^{\mathrm{a}}$ & $9.70 \pm 0,42^{\mathrm{a}}$ & $16.18 \pm 0.93^{\mathrm{a}}$ & $46.90 \pm 1.50^{\mathrm{a}}$ \\
\hline 2- CPx (150 mg/kg) & $617.71 \pm 21.52^{\mathrm{b}}$ & $198.86 \pm 11.19^{\mathrm{b}}$ & $574.14 \pm 24.97^{\mathrm{b}}$ & $8.21 \pm 0.45^{\mathrm{b}}$ & $14.37 \pm 0.56^{\mathrm{b}}$ & $44.17 \pm 0.364^{\mathrm{b}} 46.5$ \\
\hline 3- $5 \mathrm{mg} / \mathrm{kg}$ Kefir & $3615.00 \pm 88.83^{\mathrm{a}}$ & $879.33 \pm 29.63^{\mathrm{a}}$ & $694.33 \pm 22.78^{\mathrm{c}}$ & $9.81 \pm 0.46^{\mathrm{c}}$ & $16.17 \pm 0.68^{\mathrm{a}}$ & $0 \pm 0.81^{\mathrm{c}}$ \\
\hline 4- $5+150 \mathrm{mg} / \mathrm{kg} \mathrm{Kefir}+\mathrm{CPx}$ & $1347.71 \pm 75.01^{\mathrm{c}}$ & $440.00 \pm 17.55^{\mathrm{c}}$ & $629.71 \pm 35.54^{c}$ & $8.36 \pm 0.46^{\mathrm{d}}$ & $14.40 \pm 0.77^{\mathrm{b}}$ & $45.33 \pm 0.794^{\mathrm{a}} 46.0$ \\
\hline 5- $10 \mathrm{mg} / \mathrm{kg} \mathrm{Kefir}$ & $3727.86 \pm 60.49^{\mathrm{a}}$ & $843.57 \pm 62.07^{\mathrm{a}}$ & $703.71 \pm 21.68^{c}$ & $9.88 \pm 0.60^{\mathrm{c}}$ & $15.80 \pm 1.04^{\mathrm{b}}$ & $7 \pm 1.33^{\mathrm{c}}$ \\
\hline 6- $10+150 \mathrm{mg} / \mathrm{kg} \mathrm{Kefir}+\mathrm{CPx}$ & $2673.86 \pm 56.96^{\mathrm{d}}$ & $673.57 \pm 47.15^{\mathrm{d}}$ & $697.71 \pm 9.34^{\mathrm{c}}$ & $10.08 \pm 0.62^{\mathrm{c}}$ & $16.17 \pm 0.76^{\mathrm{a}}$ & $46.76 \pm 1.10^{\mathrm{a}}$ \\
\hline
\end{tabular}

*Values reported are means \pm standard deviation; means followed by different letters in same columns are significantly different $(\mathrm{p}<0.001$ :

statistically significant differences). $* *$ Means are the averages of 3 replicates.

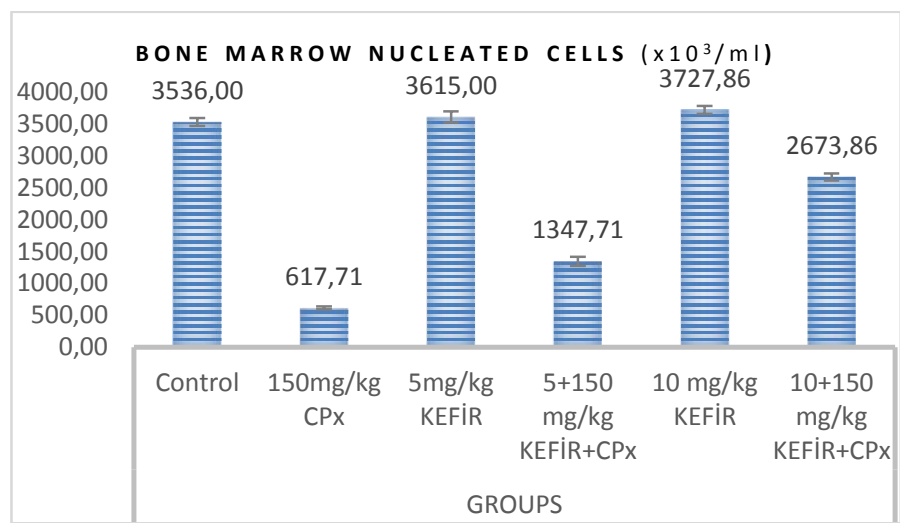

Figure 1: The effects of 5 and $10 \mathrm{mg} / \mathrm{kg}$ kefir on bone marrow nucleated cells under $150 \mathrm{mg} / \mathrm{kg} \mathrm{CPx}$ toxicity.

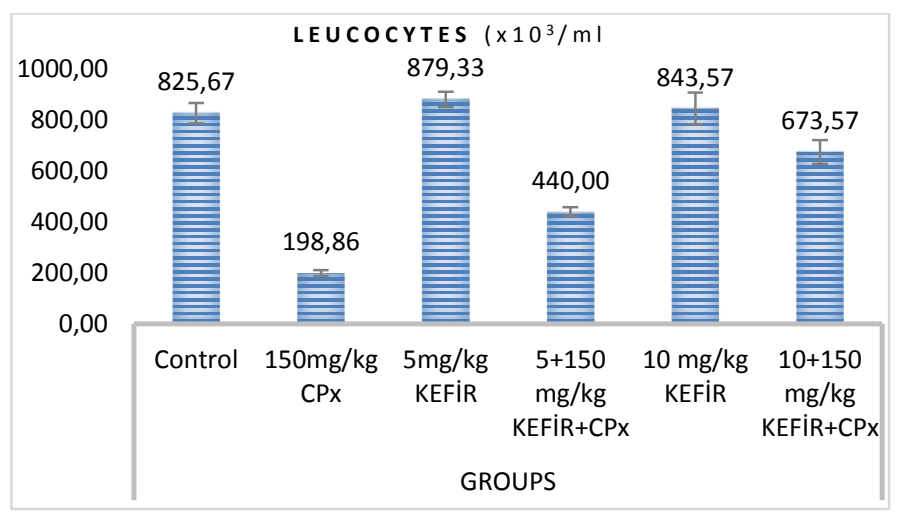

Figure 2: The effects of 5 and $10 \mathrm{mg} / \mathrm{kg}$ kefir on leukocyte count under $150 \mathrm{mg} / \mathrm{kg}$ CPx toxicity.

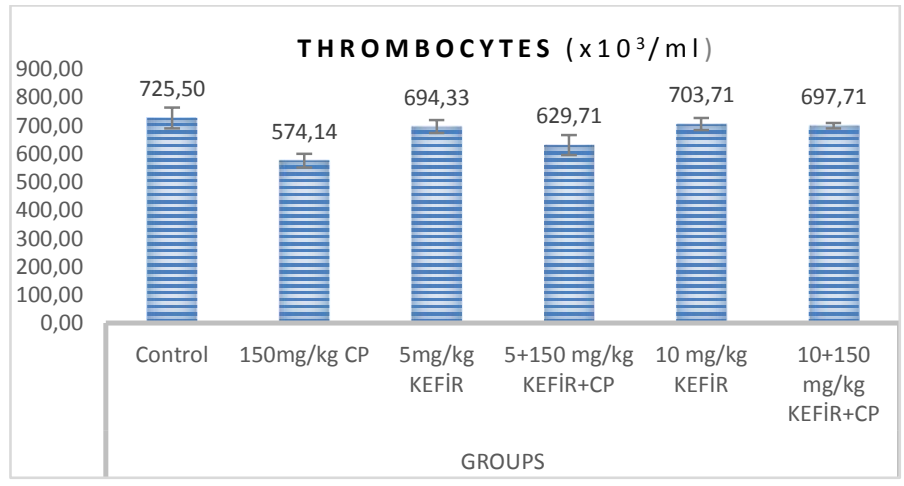

Figure 3: The effects of 5 and $10 \mathrm{mg} / \mathrm{kg}$ kefir on thrombocyte count under $150 \mathrm{mg} / \mathrm{kg}$ CPx toxicity.

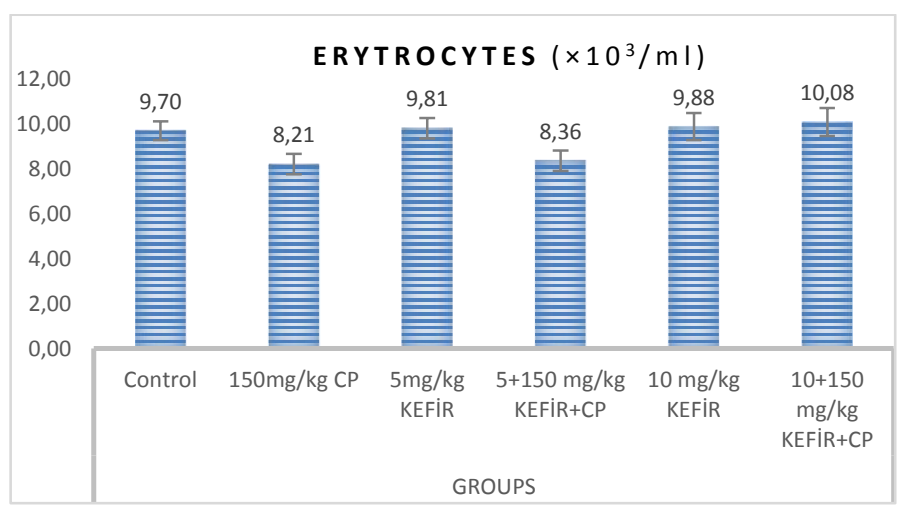

Figure 4: The effects of 5 and $10 \mathrm{mg} / \mathrm{kg}$ kefir on erythrocyte count under $150 \mathrm{mg} / \mathrm{kg}$ CPx toxicity.

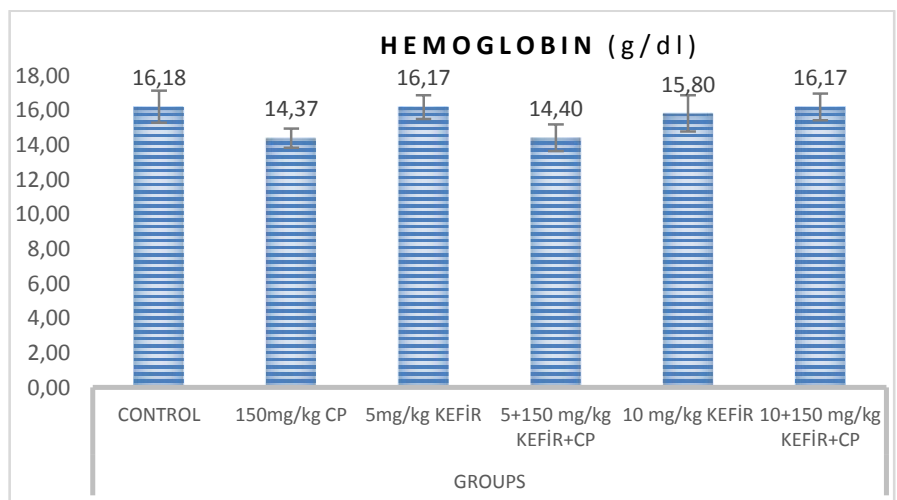

Figure 5: The effects of 5 and $10 \mathrm{mg} / \mathrm{kg}$ kefir on hemoglobin count under $150 \mathrm{mg} / \mathrm{kg} \mathrm{CPx}$ toxicity.

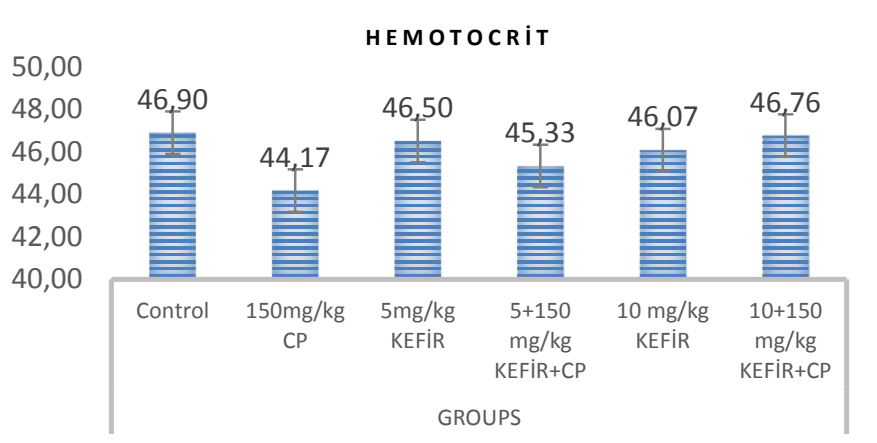

Figure 6: The protective effects of 5 and $10 \mathrm{mg} / \mathrm{kg}$ kefir on hematocrit count under $150 \mathrm{mg} / \mathrm{kg} \mathrm{CPx}$ toxicity.

\section{Discussion}

The chemical compound of kefir may differ based on the properties of the milk used, production method, microbial flora of the kefir culture used, conditions of fermentation and the 
conditions and time of storage. The reason why cow's milk was used in the present study is that most of the kefir sold in shops was fermented with cow's milk.

In a study conducted by Kubo et al. [29], it was stated that kefir, applied for 10 days, showed antitumor effect. In our study, we determined the duration of treatment with kefir as 12 days, as it was in the study of Matsuu et al. [30]. Due to the selenium, Vitamin E, catalase and superoxide dismutase enzymes in its content, kefir demonstrates an antioxidative effect and becomes an anticarcinogenic factor [31]. 24, 36, and 48 hours of kefir we used in our study showed strong antioxidant activity when compared to milk ( $\mathrm{p}<0.05$ ). However, there was not found any significant difference between the 24,36 , and 48 hours (Table 2). The microbiota in kefir grains may differ, which may cause significant changes in the taste and nutritional properties of kefir [32]. Our results showed that there was a significant difference in acidity and $\mathrm{pH}$ of 24,36 and 48 hours stored kefir $(p<0.05)$ (Table 2$)$. In many previous studies, it was reported that the $\mathrm{pH}$ value of kefir decreased in contrast with fermentation time [33-35].

The anticarcinogenic effects of kefir have been a point of emphasis for researchers in recent years [8,36,37]. Kefir demonstrates anticarcinogenic activity by decelerating the growth of cancer cells and accelerating apoptosis [38]. This anticarcinogenic effect is mostly attributed to amino acid groups that contain sulfur in their structure [39]. Although many studies were conducted on kefir and $\mathrm{CPx}$, no study on the combination of $\mathrm{CPx}$ and kefir was found in the literature. In the present experimental study, the effects of kefir, which demonstrated antioxidant activity, on blood and bone marrow in $\mathrm{CPx}$-induced hemotoxicity and myelotoxicity in rats were examined.

Chemotherapy is effective in active and rapidly growing cancer cells. Therefore, it also affects active and rapidly growing blood cells that are healthy. Myelosuppression is an unwanted side-effect of CPx chemotherapy. In the present study, the bone marrow nucleated cell level demonstrated a statistically significant decrease in the group that was administered CPx compared to the control value. In a similar study, it was reported that $\mathrm{CPx}$ reduced bone marrow nucleated cell levels and caused myelotoxicity $[26,40]$. It was reported in a previous studies that CPx-induced myelosuppression / immunotoxicity limited the use of CPx [41,42]. In the present study, when Groups 4 and 6 (which were administered kefir in combination with $\mathrm{CPx}$ ) were compared with the groups that were administered only $\mathrm{CPx}$, the bone marrow nucleated cell level demonstrated a statistically significant increase particularly in Group 6, where the levels drew near the control value $(\mathrm{p}<0.001)$ (Table 3 , Figure 1). In parallel with this finding, it was reported in previous studies that regular kefir consumption had antioxidant, anticarcinogenic and immunoregulatory effects $[7,8,35,43]$.

It was observed that in Group 2, which was administered CPx, the leukocyte count decreased in comparison with the control value. In Groups 4 and 6 , which were administered kefir in combination with $\mathrm{CPx}$, a significant increase was observed in leukocyte count. Based on this finding, it can be said that kefir demonstrates a protective effect against CPx toxicity in leukocyte cells (Table 3, Figure 2). In the CPx group, it was observed that the thrombocyte level decreased compared to the control value. In Groups 4 and 6, which were administered $\mathrm{CPx}+\mathrm{kefir}$, it was observed that this value increased to a large extent and drew near the control value (Table 3, Figure 3). Based on this, it can be said that kefir protects thrombocytes in CPx-induced toxicity, and that an increase in thrombocyte count would serve as a precaution against potential bleeding. In the CPx group, it was observed that the erythrocyte level demonstrated a statistically significant decrease in comparison with the control value. In the groups that were administered CPx+kefir (particularly Group 6), it was determined that the erythrocyte level increased significantly (Table 3, Figure 4). As can be inferred from the results of the present study, CPx has considerable toxic side-effects on proliferating healthy cells such as bone marrow and blood. In many previous studies, it was reported that bone marrow was damaged, and that the damaged or dead bone marrow stem cells were unable to produce new blood cells, causing thrombocytopenia and leukopenia $[26,44,45]$. In another study, it was reported that CPx treatment significantly reduced erythrocyte, leukocyte, thrombocyte and bone marrow nucleated cell levels [46]. In a similar experimental study, it was reported that there was a decrease in the number of bone marrow nucleated cells and the erythrocytes and leukocytes produced in the bone marrow in rats treated with CPx [47]. In a research it is reported that $\mathrm{CP}$ is toxic to bone marrow, leukocytes and platelets parallel to the dose increase [48,49]. In the present study, CPx caused leukopenia, thrombocytopenia and erythrocytopenia while it was observed that this situation improved in the groups that kefir was administered (Table 3, Figures 2-4).

In the group that was administered $\mathrm{CPx}$, it was observed that the hemoglobin level decreased significantly in comparison with the control value. In the groups that were administered kefir in combination with $\mathrm{CPx}$ (particularly Group 6), a significant increase was observed in the hemoglobin level compared to the group that was only administered CPx (Table 3, Figure 5). In 2 groups that were administered $\mathrm{CPx}$, the hematocrit level demonstrated a significant decrease compared to the control value. In Groups 4 and 6, which were administered $\mathrm{CPx}+\mathrm{kefir}$, the hematocrit level demonstrated a significant increase and drew near the control value to a large extent (Table 3, Figure 6).

In conclusion, although CPx is commonly used as a chemotherapeutic agent, its high-dose use is limited by the toxic side-effects it possesses. For this reason, new effective agents are needed to protect normal tissue from toxicity associated with chemotherapy without preserving tumor and tumor growth stimulation properties. Therefore, combining treatment regimens with antioxidant and cytoprotective properties may be beneficial in protecting healthy cells and tissue against $\mathrm{CPx}$-induced oxidative damage. As a result of the gravitation of consumer preferences towards natural probiotic/prebiotic food products in recent years, it was observed that fermented milk drinks had acquired a different position as products that were consumed in large quantities with an emphasis on human health and nutrition. For this purpose, in the present study, it was aimed to eliminate $\mathrm{CPx}$-induced toxicity on blood and bone marrow using kefir, a highly valuable fermented milk product. As a result of the present study, it was observed that kefir was able to protect blood and bone marrow cells from the toxic effects of CPx to a significant extent. The findings of the present study reinforce the idea that kefir may serve as a potentially effective component in the prevention and treatment of CPx-induced damage.

\section{References}

1. Ender G, Karagözlü C, Yerlikaya O, Akbulut N. Dünyada ve Türkiye'de tüketimi artan fermente süt içecekleri. Türkiye Bolu 9. Gida Kongresi. 2006;149-52.

2. Corthesy B, Gaskins HR, Mercenier A. Cross-talk between probiotic bacteria and the host immune system. J Nutr. 2007:137:781-90.

3. Ozyurt VH, Otles S. Prebiyotikler: Metabolizma için önemli bir gıda bileşeni. Akademik Gıda. 2014;12:115-23.

4. Otles S, Cagindi O. Kefir: A probiotic dairy-composition, nutritional and therapeutic aspects. Pak J Nutr. 2003;2:54-9. 
5. Walsh AM, Crispie F, Kilcawley K, O'Sullivan O, O'Sullivan MG, Claesson MJ, et al. Microbial succession and fla $\neg$ vor production in the fermented dairy beverage kefir. mSystems. 2016;4:1(5)

6. Purutoglu K, İspirli H, Yüzer MO, Serencam H, Dertli E. Diversity and functional characteristics of lactic acid bacteria from traditional kefir grains. Int J Dairy Technol. 2019;73:57-66.

7. Wszolek M, Tamime A, Muir D, Barclay M. Properties of kefir made in Scotland and Poland using bovine, caprine and ovine milk with different starter cultures. LWT- Food Sci Technol 2001;34:251-61.

8. Leite AMO, Miguel MAL, Peixoto RS, Rosado AS, Silva JT, Paschoalin VMF. Microbiological, technological and therapeutic properties of kefir: a natural probiotic beverage. Braz J Microbiol. 2013;44:341-9.

9. Koroglu O, Bakır E, Uludag G, Koroğlu S. Kefir and health. KSU J Agric Nat. 2015;18:26-30.

10. Ahmed Z, Wang Y, Ahmad A, Khan ST, Nisa M, Ahmad H, Afreen A. Kefir and health: a contemporary perspective. Crit Rev Food Sci Nutr. 2013;53:422-34.

11. Hacioglu G, Kurt G. Consumers' Awareness, Acceptance and Attitudes towards Functional Foods: A Research in Izmir City. Business and Economics Res J. 2012;3:161-71.

12. Adiloglu AK, Gönülateş N, İşler M, Şenol A. The effect of kefir consumption on human immune system: A cytokine study. Mikrobiyoloji Bülteni. 2013;47:273-81

13. Davras F, Tas TK, Guzel-Seydim ZB. Immunological effects of Kefir produced from Kefir grains versus starter cultures when fed to mice. Funct Foods Health Dis. 2018;8:412-23.

14. Guven A, Gulmez M. The effect of kefir on the activities of GSHPx, GST, CAT, GSH and LPO levels in carbon tetrachlorideinduced mice tissues. J Vet Med B Infect Dis Vet Public Health. 2003;50:412-6.

15. Elsayed EA, Farooq M, Dailin D, El-Enshasy HA, Othman NZ, Malek R, et al. In vitro and in vivo biological screening of kefiran polysaccharide produced by Lactobacillus kefiranofaciens. Biomed Res. 2017; 8:594-600.

16. Yildiz SC, Demir C, Cengiz M, Ayhanci A. Protective properties of kefir on burn wounds of mice that were infected with S. aureus, P. auroginasa and E. coli. Cell Mol Biol. 2019a; 65:7.

17. Kalaycioglu ME, Lichtin AE, Andrese SW, Tuason L, Bolwell BJ. High-dose busulfan and cyclophosphamide followed by autologous bone morrow transplantation and/or peripheral blood progenitor cell rescue for metastatic breast cancer. Am. J Clin Oncol. 1995;18:491-4.

18. Cavalletti E, Tofanetti O, Zunino F. Comparision of reduced glutathione with 2-mercaptoethane sulfonate to prevent cyclophosphamide induced urotoxicity. Cancer Lett. 1986;32:1-6.

19. Kumar KBH, Kuttan R. Chemoprotective activity of an extract of phyllanthus amarus against cyclophosphamide-induced toxicity in mice. Phytomed. 2004;12:494-500.

20. Shirani K, Hassani FV, Razavi-Azarkhiavi K, Heidari S, Zanjani BR, Karimi G. Phytotrapy of cyclophosphamide-induced immunosuppression. Environ Toxicol Pharmacol. 2015;39:126275.

21. Roy P, Waxman DJ. Activation of oxazaphosphorines by cytochrome P450: application to gene-directed enzyme prodrug therapy for cancer. Toxicol in Vitro 2006;20:176-86.

22. Kern JC, Kehrer JP. Acrolein-induced cell death: a caspase influenced decision between apoptosis and oncosis/necrosis. Chem Biol Interact. 2002;139:79-95.

23. MacAllister SL, Martin-Brisac N, Lau V, Yang K, O’Brien PJ. Acrolein and chloroacetaldehyde: an examination of the cell and cell-free biomarkers of toxicity. Chem Biol Interact. 2013;202:259-66.

24. Mythili Y, Sudharsan PT, Selvakumar E, Varalakshmi P. Protective effect of DL-alpha-lipoic acid on cyclophosphamide induced oxidative cardiac injury. Chem Biol Interact. 2004;151:13-9.

25. Abraham P, Isaac B. Ultrastructural changes in the rat kidney after single dose of cyclophosphamide-possible roles for peroxisome proliferation and lysosomal dysfunction in cyclophosphamide-ınduced renal damage. Hum Exp Toxicol. 2011;30:1924-30.

26. Yildiz SC, Keskin C, Sahinturk V, Ayhanci A. A Histopathological, immunohistochemical and biochemical investigation on the in vitro antioxidant, myeloprotective, hematoprotective and hepatoprotective effects of Hypericum triquetrifolium seed extract against cyclophosphamide-induced toxicity. Braz Arch Biol Technol. 2019b;62:e19180345.

27. Senthilkumar S, Devaki T, Manohar BM, Babu MS. Effect of squalene on cyclophosphamide-induced toxicity. Clinica Chimitica Acta 2006;364:335-42.

28. Marshall V. Observations on the structure of kefir grains and the distribution of the microflora. J Appl Bacteriol. 1984;57:491-7.

29. Kubo M, Odani T, Nakamura S, Tokumaru S, Matsuda H. Pharmacological study on kefir-a fermented milk product in Caucasus. I. On antitumor activity (1) (in Japanese). Yakugaku Zasshi. 1992;112:489-95.

30. Matsuu M, Shichijo K, Okaichi K, Wen CY, Fukuda E, Nakashima M, et al. The protective effect of fermented milk kefir on radiation-induced apoptosis in colonic crypt cells of rats. J Dairy Res. 2003;44:111-5.

31. Tomar O, Çağlar A, Akarca G. Kefir ve sağlık açısından önemi. AKU J Sci. 2017;027202:834-853.

32. Wang H, Sun X, Song X, Guo M. Effects of kefir grains from different origins on proteolysis and volatile profile of goat milk kefir. Food Chem. 2020;339:128099

33. Alpkent Z, Kucukcetin A. Farklı sicaklıklarda muhafaza edilen kefirlerin duyusal, fiziksel, kimyasal ve mikrobiyolojik özelliklerinde meydana gelen değişimler. Süt Mikrobiyolojisi ve Katk1 Maddeleri, VI. Süt ve Süt Ürünleri Sempozyumu Tebliğler Kitabı, Editör: Mehmet Demirci, Tekirdağ, s. 2000; 363-373.

34. Guzel-Seydim ZB, Wyffels JT, Seydim AC, Greene AK. Turkish kefir and kefir grains: microbial enumeration and electron microscobic observation. Int J Dairy Technol. 2005;58:25-29.

35. Arslan S. A review: chemical, microbiological and nutritional characteristics of kefir. CyTA-J Food. 2015;13:340-5.

36. Grishina A, Kulikova I, Alieva L, Dodson A, Rowland I, Jin J. Antigenotoxic effect of kefir and ayran supernatants on fecal water induced DNA damage in human colon cells. Nutr Cancer. 2011;63(1):73-9.

37. Ghoneum M, Gimzewski J. Apoptotic effect of a novel kefir product, PFT, on multidrug-resistant myeloid leukemia cells via a hole-piercing mechanism. Int J Oncol. 2014;44: 830-7.

38. Akbay GD. Kefirin antikarsinojenik rolü. Cumhuriyet Üniv Sağ Bil Enst Derg 2020;5:73-82.

39. Guzel-Seydim ZB, Seydim AC, Greene AK. Comparison of amino acid profiles of milk, yoğurt and Turkish kefir. Milchwissenschaft. 2003;58:158-60.

40. Moore FR, Urda GA, Krishna G, Theiss JC. An invivo/invitro method for assessing micronucleus and chromosome aberration induction in rat bone morrow and spleen. 1. Studies with cyclophosphamide. Mutat Res., Environ Mutagen Relat Subj. 1995;335:191-9.

41. Habibi E, Shokrzadeh M, Chabra A, Naghshvar F, KeshavarzMaleki R, et al. Protective effects of Origanum vulgare ethanol extract against cyclophosphamide-induced liver toxicity in mice. Pharm Biol. 2015;53:10-5.

42. Zarei M, Shivanandappa T. Amelioration of cyclophosphamideinduced hepatotoxicity by the root extract of Decalepishamiltonii in mice. Food Chem Toxicol. 2013;57:179-84.

43. Rosa DD, Dias MS, Grześkowiak LM, Reis SA, Conceiçao LL, Peluzio MCG. Milk Kefir. Nutr Res Rev. 2017;30:82-96.

44. Nafees S, Rashid S, Ali N, Hasan SK, Sultana S. Rutin ameliorates cyclophosphamide induced oxidative stress and inflammation in Wistar rats: role of NFkB/MAPK pathway. Chem Biol Interact. 2015;231:98-107.

45. Mansour HH, El Kiki SM, Hasan HF. Protective effect of Nacetylcysteine on $\mathrm{CP}$-induced cardiotoxicity in rats. Environ Toxicol Pharmacol. 2015;40:417-22.

46. Yang Y, Xu S, Xu Q, Liu X, Gao Y, Steinmetz A, et al. Protective effect of dammarane sapogenins against chemotherapy-induced myelosuppression in mice. Exp Biol Med. 2011;236:729-35.

47. Trasler JM, Hales BF, Robaire B. A timecourse study of chronic paternal cyclophosphamide treatment in rats: Effects on pregnancy outcome and the male reproductive and hematologic systems. Biol Reprod. 1987;37:317-26.

48. Cengiz, M. Hematoprotective effect of boron on cyclophosphamide toxicity in rats. Cell Mol. Bio. 2018; 64:62-5.

49. Cengiz M, Yeşildağ Ö, Ayhanci A. Siklofosfamid Nedenli Hematoksisite Üzerine Karvakrolün Sitoprotektif Etkileri. Turc J Agric Res. 2018;5:125-30. 